\title{
Mode Choice Analysis of Sustainable Public Transport in Bogor City of Indonesia
}

\author{
Moh. Nurul Iman $^{1 *} \quad$ Santun R.P Sitorus $^{2} \quad$ Machfud $^{3} \quad$ I.F Poernomosidhi Poerwo ${ }^{4} \quad$ Widiatmaka $^{5}$ \\ 1.PhD student of Natural Resources and Environmental Management Science Study Program, Bogor \\ Agricultural University, Indonesia \\ 2.Department of Soil Science and Land Resources, Faculty of Agriculture, Bogor Agricultural Institute, \\ Indonesia \\ 3.Department of Agricultural Industry Technology, Faculty of Agricultural Technology, Bogor Agricultural \\ University, Indonesia \\ 4.Research and Development Agency, Ministry of Public Works and Public Housing, Indonesia \\ 5.Department of Soil and Land Resources, Faculty of Agriculture, Bogor Agricultural University, Indonesia
}

\begin{abstract}
Public transport service scenarios must be well designed for public transport performance to be better and more sustainable. The aim of this study was to determine the percentage of the travelers move to public transportation in the Bogor City. The Stated Preference technique is used to know travelers responses to public transport service scenarios in utility functions. Furthermore, from the binomial logit model analysis obtained the probability of choice of public transportation mode. The results of the analysis have shown that the travelers responded positively to move to public transportation modes. In Corridor III, private car users and online-based motorcycle transport users choose the public transportation of non-economic medium bus type (scenario-2) with the greatest probabilities of $35.59 \%$ and $61.02 \%$. In Corridor II, private car users choose the public transportation of non-economic big bus type (scenario-3) with the greatest probability of $36.31 \%$. Motorcycle users and online-based motorcycle transport users choose the public transportation of non-economic small bus type (scenario-1) with the greatest probabilities of $66.47 \%$ and $70.64 \%$. The motorcycle users in Corridor II choose the public transportation in all scenarios with significant probabilities ranging from $62.03 \%$ to $66.47 \%$.
\end{abstract}

Keywords: mode choice analysis, public transportation, sustainable

DOI: $10.7176 / \mathrm{JESD} / 12-18-05$

Publication date:September $30^{\text {th }} 2021$

\section{Introduction}

The concept of sustainable transportation cannot be separated from the concept of sustainable development (WCED 1987). Moving on Sustainable Transportation explains that sustainable transportation aims to ensure that environmental, social and economic considerations are taken into account in decisions that affect transportation activities (Litman and Burwell 2006). Therefore, the public transportation services as an implementation of transportation development to meet the needs of mobility at this time, also may not sacrifice future generations related to mobility needs both in economic, social and environmental aspects.

The mobility of people in the Bogor City continuously increasing as seen from the high activity in the centers of socio-economic activity and the nodes of modal transfer of transportation such as the Bogor station and the bus terminal. BAPPENAS (2004) predicts that travel demand in the Jabodetabek area will increase by 26 million trips per day or $40 \%$ in 2020 , also illustrating that as part of the Jabodetabek metropolitan area, Bogor City naturally experienced the same thing. The role of public transportation is very important to serve the increasing mobility of people continuously in the city of Bogor. However, the existing types of public transportation ("angkot") with a small capacity of 8 passengers including the driver (DEPHUB 2002) with poor performance are inefficient and cause economic losses.

Mass transit with Bus Transit System (Trans Pakuan) which has been developed in three corridors in the main route network (PEMKOT 2012), is still inadequate even two corridors have not operated in the last more than six months. The performance of public transportation services is less attractive to private transportation users because they do not provide the type of service they want. BAPPENAS (2004) also predicts that if appropriate action is not taken, the low performance of public transportation services will reduce the use of public transportation modes in the Jabodetabek area from $60 \%$ in 2002 to $47 \%$ in 2020 . This also illustrates that the City of Bogor will naturally experience similar ones.

Regarding sustainable public transportation, proper policies and handling need to be done so that public transportation services become more sustainable. In addition to the performance of public transportation services, economic, social and environmental aspects must be considered in designing public transport service scenarios. However, the public transportation service scenario needs to see the response of the users or the travelers to find out what their choices are for the service scenario provided. For this reason, a study on mode choice analysis for sustainable public transport case in Bogor City of Indonesia is urgently needed. Previous studies related to the 
choice of modes of public transportation or sustainable public transport have been carried out, but in addition to the focus of the study, different parameters and methods used in the study were also carried out in the scope of regions with different characteristics.

Some of these studies include Mansyur et al. (2009) related to the sustainable passenger public transport management model, Amoroso et al. (2011) related to sustainable urban public transport, Gregorc and Krivec (2012) related to urban public transport networks for sustainable mobility, Sabeen et al. (2012) related to sustainable public transport, Dirgahayani (2012) related to urban public transport policies for sustainable urban transportation, Bachok et al. (2014) about the perspective of passengers for the identification of sustainable public transport services, Ryley et al. (2014) related to Demand Responsive Transport (DRT) for the development of a sustainable public transportation system, Ponrahono et al. (2015) related to sustainable urban public transport systems, Bachok et al. (2015) related to sustainable public transport indicators, and Mupfumira and Wirjodirdjo (2015) related to an approach to a dynamic system of urban public transportation that is economically sustainable. Silitonga et al. (2011) related mode choice models in Indonesia to complete the use of private transport intended for public transportation use, and Ahern and Tapley (2008) related perceptions and preferences of inter-city train and bus passengers and their comparisons.

The aim of this study was to determine the percentage of the travelers move to public transportation in the Bogor City, Indonesia.

\section{Methodology}

\subsection{Method of collecting data}

Preference from the travelers are needed to get the utility function of the choice of urban public transportation modes in Bogor City. Primary data of the preferences travelers obtained directly from the field through direct interview surveys with stated preference techniques. According to Kroes and Sheldon (1988), stated preference methods are techniques that use respondent statements individually about their preferences in a set of transportation choices to estimate utility functions. The choice is a description of the types of situations or transportation context developed by the researcher. By their nature, stated preferences require surveys that are designed with the aim of collecting data. The survey is to obtain data on the response of travelers from each alternative mode choice offered.

Data collection using stated preference techniques in this study was carried out on three segments of private car users, motorcycle users, and online-based motorcycle transportation users. The data collection to find out their response to intervention scenarios for more sustainable public transport and came up with probability of those switching to public transportation mode in each scenario. The current segment of public transport users ("angkot") is a captive user so it is assumed to continue to choose the public transportation provided. The number of respondents in the survey research with these stated preference techniques, Hensher (2003) stated that a minimum of 30 respondents and an optimal of 50 respondents, Ahern and Tapley (2008) used 40 questionnaires in a study of case mode selection models in Ireland. In this study interviews were conducted with 60 respondents for each segment.

Sustainability of public transportation in urban areas of Bogor City in terms of sustainable transportation indicators according to The World Bank (1996), Litman dan Burwell (2006), Schiller et al. (2010), Brotodewo (2010), Kennedy (2001), and Kumar (2014) and aspects of service performance. In accordance with the relevance of the conditions and characteristics of the service, the sustainability of public transportation can be viewed from: a) the mode share of the use of public transportation modes, b) savings in vehicle operating costs, c) savings in travel time value, d) savings in pollution value, e) public transportation facilities and services for users with disabilities, f) safety of public transport, g) availability of a mass transit system, h) consumption of fossil fuels for public transport, i) traffic noise level, k) emissions vehicle caused by traffic volume, 1) headway, m) load factor, n) waiting time, and o) public transport operation performance. Intervention scenarios for variables and types of public transportation are developed so that public transportation is more sustainable. The scenarios are designed for public transport services on the main route network of Corridor III (Bubulak - Baranangsiang) and Corridor II (Baranangsiang - Ciawi). The scenarios use three types of public transportation services, namely scenario-1: non-economic small bus type, scenario-2: non-economic medium bus type, and scenario-3: noneconomic big bus type. The service attributes and specifications of each scenario are grouped as Table 1 (Corridor III: Bubulak - Baranangsiang) and Table 2 (Corridor II: Baranangsiang - Ciawi). The attributes and specifications of each scenario are compared with public transportation types ("angkot") used today. 
Table 1 Public transport service attributes and specifications (Corridor III: Bubulak - Baranangsiang)

\begin{tabular}{|c|c|c|c|}
\hline \multirow{2}{*}{ Attributes } & \multicolumn{3}{|c|}{ Public Transportation Services } \\
\hline & Scenario-1 & Scenario-2 & Scenario-3 \\
\hline \multicolumn{4}{|l|}{ Atribut $1\left(\mathrm{X}_{1}\right)$ : } \\
\hline - Travel time* & $40 \%$ shorter & $60 \%$ shorter & $60 \%$ shorter \\
\hline $\begin{array}{l}\text { - Duration of stops at bus stops or up and } \\
\text { down facilities of passengers }\end{array}$ & $\leq 1$ minute & $\leq 0.5$ minute & $\leq 0.5$ minute \\
\hline - Facilities for disability passengers & $\begin{array}{c}\text { Not } \\
\text { available }\end{array}$ & $\begin{array}{l}\text { Available ( } 1 \text { seat } \\
\text { priority) }\end{array}$ & $\begin{array}{c}\text { Available ( } 2 \text { seat priority, } 1 \\
\text { wheelchair space) }\end{array}$ \\
\hline \multicolumn{4}{|l|}{ Atribut $2\left(\mathrm{X}_{2}\right)$ : } \\
\hline - Service time & $\begin{array}{l}\text { Every } 3 \\
\text { minutes }\end{array}$ & Every 5 minutes & Every 8 minutes \\
\hline - Fare & $\operatorname{Rp} 4.500$ & Rp 5.500 & $\operatorname{Rp} 6.500$ \\
\hline - Carried passengers & Sit all & $\begin{array}{l}75 \% \text { sit }+25 \% \\
\text { stand up }\end{array}$ & $62 \%$ sit $+38 \%$ stand up \\
\hline \multicolumn{4}{|l|}{ Atribut $3\left(\mathrm{X}_{3}\right)$ : } \\
\hline - Change mode & $\leq 2$ times & $\leq 2$ times & $\leq 2$ times \\
\hline - Walking distance to public transportation & $\leq 300$ meters & $\leq 300$ meters & $\leq 300$ meters \\
\hline
\end{tabular}

* are compared with public transportation types ("angkot") used today

Table 2 Public transport service attributes and specifications (Corridor II : Baranangsiang - Ciawi)

\begin{tabular}{|c|c|c|c|}
\hline \multirow{2}{*}{ Atribut } & \multicolumn{3}{|c|}{ Public Transportation Services } \\
\hline & Scenario-1 & Scenario-2 & Scenario-3 \\
\hline \multicolumn{4}{|l|}{ Atribut $1\left(\mathrm{X}_{1}\right)$ : } \\
\hline - Travel time* & $20 \%$ shorter & $45 \%$ shorter & $45 \%$ shorter \\
\hline $\begin{array}{l}\text { - Duration of stops at bus stops or up and } \\
\text { down facilities of passengers }\end{array}$ & $\leq 1$ minute & $\leq 0.5$ minutes & $\leq 0.5$ minutes \\
\hline - Facilities for disability passengers & $\begin{array}{c}\text { Not } \\
\text { available }\end{array}$ & $\begin{array}{l}\text { Available (1 seat } \\
\text { priority) }\end{array}$ & $\begin{array}{c}\text { Available ( } 2 \text { seat priority, } 1 \\
\text { wheelchair space) }\end{array}$ \\
\hline \multicolumn{4}{|l|}{ Atribut $2\left(\mathrm{X}_{2}\right)$ : } \\
\hline - Service time & $\begin{array}{l}\text { Every } 5 \\
\text { minutes }\end{array}$ & Every 8 minutes & Every 10 minutes \\
\hline - Fare & $\operatorname{Rp} 4.000$ & Rp 5.000 & $\operatorname{Rp} 6.000$ \\
\hline - Carried passengers & Sit all & $\begin{array}{l}75 \% \text { sit }+25 \% \\
\text { stand up }\end{array}$ & $62 \%$ sit $+38 \%$ stand up \\
\hline \multicolumn{4}{|l|}{ Atribut $3\left(\mathrm{X}_{3}\right)$ : } \\
\hline - Change mode & $\leq 2$ times & $\leq 2$ times & $\leq 2$ times \\
\hline - Walking distance to public transportation & $\leq 300$ meters & $\leq 300$ meters & $\leq 300$ meters \\
\hline
\end{tabular}

* are compared with public transportation types ("angkot") used today

Based on the public transportation service attributes and specifications of each scenario as Table 1 and Table 2 an experimental design was made to obtain preferences from the travelers and further analysis as in Table 3.

Table 3 Experimental design of public transport service level of each attribute

\begin{tabular}{|c|c|c|c|c|}
\hline \multirow{2}{*}{ Scenarios } & \multicolumn{3}{|c|}{ Attributes Level of Public Transport Services } & \multirow[t]{2}{*}{ Choice* } \\
\hline & $\mathrm{X}_{1}$ & $\mathrm{X}_{2}$ & $\mathrm{X}_{3}$ & \\
\hline \multicolumn{5}{|c|}{ Corridor III : Bubulak - Baranangsiang : } \\
\hline Scenario-1 & 0 & 2 & 1 & $0 / 1$ \\
\hline Scenario-2 & 1 & 1 & 1 & $0 / 1$ \\
\hline Scenario-3 & 1 & 0 & 1 & $0 / 1$ \\
\hline \multicolumn{5}{|c|}{ Corridor II : Baranangsiang - Ciawi : } \\
\hline Scenario-1 & 0 & 2 & 1 & $0 / 1$ \\
\hline Scenario-2 & 1 & 1 & 1 & $0 / 1$ \\
\hline Scenario-3 & 1 & 0 & 1 & $0 / 1$ \\
\hline
\end{tabular}

* $0=$ not choosing public transportation; $1=$ choosing public transportation

\subsection{Data analysis method}

The analysis was carried out to obtain the utility function and the probability of choice of modes of public 
transportation in the city of Bogor in each segment of the travelers. According to Pearmain and Swanson (1991) that utility is the satisfaction of someone spending their limited funds for something different. Utility is the value given to a product and is assumed to be the maximum utility. This study uses the utility function as stated by Kroes and Sheldon (1988) and Pearmain and Swanson (1991) with a linear model that is : $\mathrm{U}_{\mathrm{PT}}=\mathrm{a}_{0}+\mathrm{a}_{1} \cdot \mathrm{x}_{1}+$ $\mathrm{a}_{2} \cdot \mathrm{x}_{2}+\mathrm{a}_{3} \cdot \mathrm{x}_{3}$ with $\mathrm{U}_{\mathrm{PT}}$ is utility of public transport option, $\mathrm{a}_{0}$ is model constant, $\mathrm{a}_{1}, \mathrm{a}_{2}$ dan $\mathrm{a}_{3}$ are model coefficients of public transport attributes, and $\mathrm{x}_{1}, \mathrm{x}_{2}$ and $\mathrm{x}_{3}$ are public transport attributes.

The probability of choice of public transport modes uses discrete choice models as probabilistic models Pearmain and Swanson (1991). Discrete choice models are probabilistic models that the value of each choice of respondents relates to other choices in a set of alternatives offered Pearmain and Swanson (1991). The most common form of this model is the logit function. The most popular analysis technique for this method is logit analysis. The probability of choice of public transport modes in this study uses discrete choice models with the Binominal Logit Model that is : $\mathrm{P}_{\mathrm{PT}}=1 /\left(1+\exp \left(\mathrm{U}_{\mathrm{C}}-\mathrm{U}_{\mathrm{PT}}\right)\right)$ with $\mathrm{P}_{\mathrm{PT}}$ is probability of choosing public transport, $\mathrm{U}_{\mathrm{PT}}$ is utility of public transport, and $\mathrm{U}_{\mathrm{C}}$ is utility of non public transport.

\section{Results And Discussion}

Analysis was carried out on several alternative scenarios of public transportation services in the main route network within the Bogor City area Corridor III (Bubulak - Baranangsiang) and Corridor II (Baranangsiang Ciawi). The mode choice model of urban public transportation, namely the utility function and binomial logit model, was developed based on the preferences of the travelers. The results of the analysis using the binomial logit model obtained utility functions and logit models for private car users (PCU), motorcycle users (MCU), and online-based motorcycle transport users (OMCU).

Corridor III : Bubulak - Baranangsiang :

a. For private car users (PCU):

$\mathrm{U}_{\mathrm{PT}}=-4.22552+2.83922 * \mathrm{X}_{1}+0.79323 * \mathrm{X}_{2}$

$\mathrm{P}_{\mathrm{PT}}=1 /\left(1+\exp \left(-\left(-4.22552+2.83922 * \mathrm{X}_{1}+0.79323 * \mathrm{X}_{2}\right)\right)\right)$

b. For motorcycle users (MCU):

$\mathrm{U}_{\mathrm{PT}}=-1.85238-22.78519 * \mathrm{X}_{2} ; \mathrm{P}_{\mathrm{PT}}=1 /\left(1+\exp \left(-\left(-1.85238-22.78519 * \mathrm{X}_{2}\right)\right)\right)$

c. For online-based motorcycle transport users (OMCU):

$\mathrm{U}_{\mathrm{PT}}=-2.32238+1.47508 * \mathrm{X}_{1}+1.29532 * \mathrm{X}_{2}$

$\left.\mathrm{P}_{\mathrm{PT}}=1 /\left(1+\exp \left(-\left(-2.32238+1.47508 * \mathrm{X}_{1}+1.29532 * \mathrm{X}_{2}\right)\right)\right)\right)$

Corridor II : Baranangsiang - Ciawi :

a. For private car users (PCU): $\left.\mathrm{U}_{\mathrm{PT}}=-0.56194-0.07365 * \mathrm{X}_{2} ; \mathrm{P}_{\mathrm{PT}}=1 /\left(1+\exp \left(-\left(-0.56194-0.07365 * \mathrm{X}_{2}\right)\right)\right)\right)$

b. For motorcycle users (MCU): $\left.\mathrm{U}_{\mathrm{PT}}=+0.49071+0.09677 * \mathrm{X}_{2}\right) ; \mathrm{P}_{\mathrm{PT}}=1 /\left(1+\exp \left(-\left(+0.49071+0.09677 * \mathrm{X}_{2}\right)\right)\right)$

c. For online-based motorcycle transport users $(\mathrm{OMCU})$ : $\mathrm{U}_{\mathrm{PT}}=+0.69687+\left(0.09047 * \mathrm{X}_{2}\right) ; \mathrm{P}_{\mathrm{PT}}=1 /\left(1+\exp \left(-\left(+0.69687+0.09047 * \mathrm{X}_{2}\right)\right)\right)$

The model is used to predict the choice probability of travelers for urban public transport service scenarios. Based on the results of calculations using the model, the choice probability of public transportation modes in each scenario for each segment of the travelers are as shown in Table 4.

Table 4 The choice probability of public transportation modes based on scenarios and segments of the travelers

\begin{tabular}{|c|c|c|c|c|c|c|}
\hline \multirow{2}{*}{$\begin{array}{c}\text { The scenarios of public } \\
\text { transportation service }\end{array}$} & \multicolumn{5}{|c|}{ Segments of the travelers } \\
\cline { 2 - 7 } & \multicolumn{3}{|c|}{ Corridor III } & Corridor II \\
\cline { 2 - 7 } & PCU & MCU & OMCU & PCU & MCU & OMCU \\
\hline Scenario-1 & $6.67 \%$ & $0.00 \%$ & $56.67 \%$ & $32.98 \%$ & $66.47 \%$ & $70.64 \%$ \\
\hline Scenario-2 & $35.59 \%$ & $0.00 \%$ & $61.02 \%$ & $34.62 \%$ & $64.28 \%$ & $68.73 \%$ \\
\hline Scenario-3 & $20.00 \%$ & $13.56 \%$ & $30.00 \%$ & $36.31 \%$ & $62.03 \%$ & $66.75 \%$ \\
\hline
\end{tabular}

The choice of public transportation modes as Table 4 shows that in general there are travelers who move to public transportation modes in each scenario. In Corridor III, PCU and OMCU are willing to choose public transportation scenario- 2 with the highest probability, namely $35.59 \%$ and $61.02 \%$, respectively. The MCU are willing to choose public transportation only scenario-3 with a probability of $13.56 \%$. In Corridor II, PCU willing to choose public transportation scenario-3 with the largest probability of $36.31 \%$. As for MCU and $\mathrm{OMCU}$, they are willing to choose public transportation scenario-1 with the highest probability, namely $66.47 \%$ and 70.64, respectively. MCU in Corridor II are willing to choose public transportation in all scenarios with a significant probability ranging from $62.03 \%$ to $66.47 \%$. This is different from Corridor III, which is only willing to choose scenario-3 with a less large probability.

A positive response to the move of travelers to public transportation can encourage the sustainability of public transportation. This public transportation service scenarios as a policy intervention can increase public transport share modes, disability user facilities, public transport security, the existence of a mass public transport 
system, load factor of public transport, and public transport service performance which are indicators of sustainable public transportation. In addition, these policy interventions can reduce vehicle operating costs, travel time values, and motor vehicle emissions which are also indicators of sustainable public transport.

\section{Conclusion}

A policy scenario is needed so that urban public transportation in Bogor City becomes more sustainable. Several public transportation service scenarios can be used to intervene indicators that can be a lever for the sustainability of public transportation. These scenarios are public transport services using non-economic small bus type (scenario-1), non-economic medium bus type (scenario-2), and non-economic big bus type (scenario-3). However, to the extent that these scenarios are acceptable to the travelers so that they will move to using public transportation, it is necessary to analyze their preferences for the given scenarios. In general, the travelers gave a positive response to the scenarios of public transport services both in the case of Corridor III and Corridor II. This can be seen from the preference of those who are willing to move to public transportation modes. In Corridor III, PCU and OMCU choose public transportation of non-economic medium bus type (scenario-2) with the greatest probability of $35.59 \%$ and $61.02 \%$, respectively. In Corridor II, PCU choose public transportation of non-economic big bus type (scenario-3) with the greatest probability of $36.31 \%$. MCU and OMCU choose public transportation of non-economic small bus type (scenario-1) with the greatest probability of $66.47 \%$ and $70.64 \%$, respectively. The MCU in Corridor II choose public transportation in all scenarios with a significant probability ranging from $62.03 \%$ to $66.47 \%$.

\section{References}

Amoroso, S., Salvo, G., Zito, P. (2011). Sustainable Urban Public Transport : A Comparison Between European and North African Cities. $\quad$ Proceedings. In : The $12^{\text {th }}$ Management International Conference Portoroz. Slovenia (SI): University of Palermo

Ahern, A.A., Tapley, N. (2008). The use of stated preference techniques to model modal choices on interurban trips in Ireland. Transportation Research Part A, 42(0), 15-27

Badan Perencanaan Pembangunan Nasional RI. (2004). Studi Rencana Induk Transportasi Terpadu Jabodetabek Tahap 2. Jakarta [ID] : BAPPENNAS

Bachok, S., Osman, M.M., Ponrahono, Z. (2014). Passenger's Aspiration towards Sustainable Public Transportation System : Kerian District, Perak, Malaysia. Procedia Social and Behavioral Sciences, 153(0), 553-565

Bachok, S., Ponrahono, Z., Osman, M.M., Jaafar, S., Ibrahim, M., Mohamed, M.Z. (2015). A Preliminary Study of Sustainable Transport Indicators in Malaysia: The Case Study of Klang Valley Public Transportation. Procedia Environmental Sciences, 28(0), 464-473

Brotodewo N. (2010). Penilaian Indikator Transportasi Berkelanjutan pada Kawasan Metropolitan di Indonesia. Jurnal Perencanaan Wilayah dan Kota. 21(3):165-182

Departemen Perhubungan RI. (2002). Keputusan Direktur Jenderal Perhubungan Darat Nomor : SK.687/AJ.206/DRJD/2002 Tentang Pedoman Teknis Penyelenggraan Angkutan Penumpang Umum di Wilayah Perkotaan Dalam Trayek Tetap dan Teratur. Jakarta (ID): DEPHUB

Dirgahayani. (2012). Policy Elements to Upscale the Contribution of Urban Transit Initiatives on Sustainable Urban Transport: The Case of Bus Improvement Initiatives in Indonesia. UNU-IAS Working Paper No. 168. Tokyo (JP): United Nations University

Gregorc, C., Krivec, D. (2012). Networking of Public Passengers Transport Modes, A Step Towards Sustainable Mobility in Ljubljana Urban Region. Procedia Social and Behavioral Sciences. 48(0), 3009-3017

Hensher, D.A. (2003). Revealing Differences in Willingness to Pay due to the Dimensionality of Stated Choice Designs: An Initial Assessment. Working Paper ITS-WP-03-08. Australia (AU): Institute Of Transport Studies

Kennedy CA. (2001). A Comparison of the Sustainability of Public and Private Transportation Systems: Study of the Greater Toronto Area. Canada (CA): Department of Civil Engineering, University of Toronto

Kroes, E.P., Sheldon, R.J. (1988). Stated Preference Methods in Transport Research. Journal of Transport Economics and Policy. 22(1), 11-25

Kumar M. (2014). Sustainable Urban Transport Indicators. TERI-NFA Working Paper No. 12. India (IN): The Energy and Resources Institute

Litman, T., Burwell, D. (2006). Issues in sustainable transportation. Int. J. Global Environmental Issues, 6(4), 331-347

Mansyur U, Sitorus SRP, Marimin, Prasetyo LB, Poerwo IFP. (2009). Model Pengelolaan Transportasi Angkutan Umum Penumpang Non Bus Berkelanjutan Kota Makassar. Forum Pascasarjana, 32(4), 227-237

Mupfumira, P., Wirjodirdjo, B. (2015). An Economically Sustainable Urban Public Transport Framework: System Dynamics Modelling Approach to Reduce Public Transport Liberalisation Impact in Harare City, 
Zimbabwe. International Journal of Science, Technology and Society, 3(2), 11-21

Pemerintah Kota Bogor. (2012). Peraturan Walikota Bogor Nomor 17 Tahun 2012 Tentang Penyelenggaraan Sistem Angkutan Umum Massal (SAUM) Di Kota Bogor. Bogor (ID): PEMKOT

Ponrahono, Z., Osman, M.M., Bachok, S., Ibrahim, M. (2015). Sustainable Urban Public Transportation System in Malaysia : A Comparison of Bus Services in Kuantan and Penang. Proceedings. In : International Conference on Development and Socio Spatial Inequalities 18-20 August 2015. Malaysia (MY): Universiti Sains Malaysia

Pearmain, D., Swanson, J. (1991). Stated Preference Techniques A Guide To Practice. Steer Davies Gleave. Netherlands (NL): Hague Consulting Group

Ryley, T.J., Stanley, P.A., Enoch, M.P., Zanni, A.M. (2014). Investigating the contribution of Demand Responsive Transport (DRT) to a sustainable local public transport system. Research in Transportation Economics, 48(0), 364-372

Sabeen, A.H.H., Anwar, A.E., Noor, Z.Z. (2012). Sustainable Public Transportation in Malaysia. International Journal of Engineering and Advanced Technology (IJEAT), 1(5), 71-74

Schiller PL, Bruun EC, Kenworthy JR. (2010). An Introduction to Sustainable Transportation : Policy, Planning and Implementation. Washington (US): Earthscan Ltd

Silitonga, S.P., Sulistio, H., Djakfar, L., Wicaksono, A. (2011). Modal Split Model for Public Transport Development in Indonesia. Journal of Applied Sciences Research, 7(12), 2036-2041

The World Bank. (1996). Sustainable Transport : Priorities For Policy Reform, Washington (US): The World Bank

World Commission on Environment and Development. (1987). Report of World Commission on Environment and Development : Our Common Future. America (S): Oxford University Press 